\section{$\underset{\text { hommes }}{\text { \& migrations }}$}

\section{Hommes \& migrations}

Revue française de référence sur les dynamiques

migratoires

$1298 \mid 2012$

France - Algérie, le temps du renouveau

\title{
La Vierge, les Coptes et moi
}

Film égyptien de Namir Abdel Messeeh

\section{André Videau}

\section{OpenEdition \\ 1 Journals}

\section{Édition électronique}

URL : http://journals.openedition.org/hommesmigrations/1597

DOI : 10.4000/hommesmigrations. 1597

ISSN : 2262-3353

\section{Éditeur}

Musée national de l'histoire de l'immigration

\section{Édition imprimée}

Date de publication : 1 juillet 2012

Pagination : 158

ISSN : 1142-852X

\section{Référence électronique}

André Videau, « La Vierge, les Coptes et moi », Hommes \& migrations [En ligne], 1298 | 2012, mis en ligne le 29 mai 2013, consulté le 22 septembre 2020. URL : http://journals.openedition.org/ hommesmigrations/1597; DOI : https://doi.org/10.4000/hommesmigrations.1597

Ce document a été généré automatiquement le 22 septembre 2020.

Tous droits réservés 


\title{
La Vierge, les Coptes et moi
}

\author{
Film égyptien de Namir Abdel Messeeh
}

\section{André Videau}

1 Namir Abdel Messeeh, jeune réalisateur français d'origine égyptienne, a un projet de documentaire qui lui tient à cœur, mais n'emballe personne.

2 Ni sa famille, ni son producteur. Il s'agit de décrypter le culte que la communauté voue à la Vierge Marie sous sa forme la plus fervente et la plus troublante : cles apparitions. Musulmans et chrétiens partagent cette croyance. On a beau vouloir dévoiler le mystère et détecter les supercheries, il ne faut pas froisser les susceptibilités, surtout si l'on est un jeune homme qui s'est exilé et a rompu avec la religion. L'Égypte compte environ 7 millions de coptes, soit $10 \%$ de sa population (le chiffrage exact reste un sujet tabou et leur place disputée dans la société égyptienne, un ferment de discorde).

En butte à des difficultés de tous ordres, le film va se modifier au gré de sa fabrication.

4 L'enquête sur les miracles devient une quête familiale et une reconquête des siens.

5 Avec une équipe réduite, un minimum de matériel et un budget limité, Namir se retrouve dans la cohue du Caire qui ne lui est plus familière depuis longtemps. Son projet a plus de chances de trouver un terrain favorable en Haute-Égypte, dans la région d'Assiout, où se concentre, entre misère humaine et luxuriance des paysages, une importante communauté copte, parmi laquelle une kyrielle de parents et alliés, oncles, tantes, cousins et neveux, sans oublier une irrésistible grand-mère, toujours prête à secouer sa mémoire et sa surdité pour se mettre en vedette.

6 En bonne mère orientale, autoritaire et volubile, la mère de Namir suit de Paris, où elle réside, la carrière balbutiante de son fils et l'avancée du projet. Elle ne se satisfait guère des tergiversations de ce dadais de Namir qui semble céder au vertige dynastique, se passionner pour la saga familiale et négliger les formalités. Son arrivée inopinée sur les lieux de tournage va redynamiser le film. Elle sait réactiver les réseaux, créer un climat de confiance, mettre dans sa poche les fidèles, les sceptiques et... le pape.

7 Ancienne banquière du côté des Émirats, elle sait surtout s'adapter aux difficultés financières. Exit le producteur parisien, râleur et radin, le film décidément évolutif va s'inspirer des circonstances. Puisque la Vierge Marie ne daigne pas apparaître devant 
les foules extasiées du pèlerinage de Zeitoun où elle avait ses habitudes, puisque les visionnaires locaux se font tirer l'oreille pour apporter leur témoignage, les gens du cinéma vont se charger de la mise en scène et les habitants de l'interprétation. C'est une apothéose plus jubilatoire que blasphématoire mais elle est provisoire car déjà remontent les vacarmes printaniers et les rumeurs de la place Tahrir.

8 Comme la madone, la liberté sera-t-elle au rendez-vous? Ou pas? 